\title{
Eksplorasi Tipe Kepribadian Big Five Personality Traits Dan Pengaruhnya Terhadap Prestasi Akademik
}

\author{
Asina Christina Rosito \\ Psikologi Pendidikan, Universitas HKBP Nommensen \\ asina.christina@hotmail.com
}

(Diterima: 07-Juni-2017; direvisi: 16-Mei-2018; dipublikasikan: 24-Juni-2018)

\begin{abstract}
The aim of this study were to explore the type of personality based on Big Five Personality Traits model, to explore the academic achievement, and to investigate the effect of personality on academic achievement in college students. The participants are 321 students at University of HKBP Nommensen in 2015-2016 academic year. The instrument used for assessing the personality was the Big Five Personality Scale (includes dimensions neuroticsm, extraversion, conscientiousness, agreeableness, dan openness). Based on the descriptive analysis, it was found that most of the participants are classified in neuroticsm type. Related with the academic achievement, higher GPA was dominated by female students (GPA $\geq 2.75$ ). Based on the regression analysis, it was found that personality effect the academic achievement significantly $\left(R=0,26 ; R^{2}=6,9 \% ; F=4,69\right.$; $\mathrm{p}$-value $<0,001)$. Based on the advance analysis of each dimension's contribution for academic achievement, it was found that neuroticsm, extraversion, conscienstiousness are significantly effected academic achievement.
\end{abstract}

Keyword: Big Five Personality Traits; academic achievement

Abstrak : Penelitian ini bertujuan untuk mengetahui gambaran tipe kepribadian berdasarkan model Big Five Personality Traits, gambaran prestasi akademik, dan pengaruh kepribadian terhadap prestasi akademik pada mahasiswa Universitas HKBP Nommensen. Partisipan penelitian adalah 321 mahasiswa aktif pada semester genap TA. 2015/2016. Instrumen penelitian yang digunakan untuk mengukur kepribadian adalah Skala Big Five Personality (mencakup 5 dimensi kepribadian: neuroticsm, extraversion, conscientiousness, agreeableness, dan openness). Prestasi akademik diukur dari nilai Indeks Prestasi Kumulatif (IPK) pada semester genap TA. 2015/2016. Hasil analisa deskriptif menunjukkan bahwa tipe kepribadian yang paling banyak muncul adalah tipe kepribadian neuroticsm disusul dengan tipe kepribadian extraversion, conscientiousness, agreeableness, dan openness. Berdasarkan hasil analisa deskriptif terhadap prestasi akademik diketahui bahwa prestasi akademik yang tinggi (IPK $\geq 2.75$ ) didominasi oleh mahasiswa perempuan. Berdasarkan hasil uji hipotesis menggunakan analisis regresi, diketahui bahwa kepribadian dengan model Big Five Personality Traits ini memberikan pengaruh signifikan terhadap prestasi akademik $\left(\mathrm{R}=0,26 ; \mathrm{R}^{2}=6,9 \% ; \mathrm{F}=4,69 ;\right.$ p-value $<0,001)$. Berdasarkan hasil uji regresi selanjutnya untuk mengidentifikasi kontribusi dan signifikansi dari tiap dimensi kepribadian, diperoleh hasil bahwa dimensi neuroticsm, exstraversion, dan conscienstiousness berpengaruh secara signifikan terhadap prestasi akademik.

Kata kunci: Big Five Personality Traits; prestasi akademik

Copyright $\odot 2018$ Universitas Negeri Makassar.. This is an open access article under the CC BY-NC-ND license (http://creativecommons.org/licenses/by-nc-nd/4.0/). 


\section{PENDAHULUAN}

Pendidikan merupakan pilar utama dalam membangun dan memajukan negara. Oleh karena itu, berbagai pihak yang terlibat dalam pendidikan perlu terus mengupayakan hal-hal yang mendorong meningkatnya pencapaian kompetensi para pembelajar, sesuai dengan tingkat pendidikan dan bidang keilmuannya. Dalam dunia internasional, pendidikan sering sekali dijadikan sebagai indikator kemajuan suatu negara, selain aspek ekonomi dan teknologi. Berbagai lembaga survey berusaha memberikan gambaran tentang tingkat pendidikan negara-negara baik dalam skala regional, maupun internasional sebagai upaya melakukan perbandingan dalam berbagai item indikator kemajuan pendidikan. Contohnya, PISA (Program for International Student Assessment), program riset yang berskala internasional yang merupakan salah satu program kerjasama di beberapa negara yang tergabung dengan OECD (Organization for Economic Co-operation and Development) dan memiliki tujuan untuk melihat perbandingan kemampuan akademis siswa berumur 15 tahun di berbagai negara dalam bidang matematika, sains, dan membaca. Dari hasil risetnya pada tahun 2012, diperoleh informasi bahwa rata-rata nilai siswa-siswi Indonesia menempati urutan kedua paling bawah dari total 65 negara alias di urutan 64 dari 65 negara yang terlibat (http://edukasi.kompasiana.com/2014/08/27/kon disi-pendidikan-negara-dan-hasil-survey-670937 .html, diakses 2 April 2015). Contoh lainnya, TIMSS (Trends in International mathematics and Science Study) merupakan suatu studi berskala internasional yang bertujuan mengukur prestasi dalam bidang matematika dan sains di siswa tingkat sekolah menengah pertama. Dari hasil studi tersebut, diperoleh informasi bahwa rata-rata nilai skor matematik untuk siswa Indonesia berada signifikan di bawah rata-rata nilai internasional, tetapi tidak jauh berbeda dengan negara lainnya dalam rata-rata nilai sains (http://litbang.kemdikbud.go.id/index.php/survei -internasional-timss, diakses pada 1 April 2015). Dari beberapa hasil survei tersebut, ada indikasi bahwa hasil dan kualitas pendidikan Indonesia masih berada pada urutan bawah ketika dibandingkan dengan negara-negara lainnya. Berbagai indikator dari keberhasilan proses pembelajaran telah dikembangkan, baik yang sifatnya terstandarisasi di tingkat internasional, nasional dan regional, maupun pengukuran prestasi pembelajaran yang dikembangkan oleh pihak sekolah atau pendidik sendiri. Berbagai asesmen pembelajaran tersebut pada dasarnya bertujuan untuk mengetahui sejauh mana pencapaian pembelajaran siswa bila dibandingkan dengan tujuan instruksional pembelajaran. Penilaian yang dilakukan dari berbagai asesmen pembelajaran tersebut itulah yang sering disebut sebagai prestasi belajar. Beberapa istilah lain yang digunakan untuk prestasi belajar antara lain academic performance (Buju, 2013; Hazrati-Viari, Rad \& Torabi, 2012) dan academic achievement (Komarajju, Karau, Schmeck \& Avdic, 2011). Peneliti dalam hal ini menggunakan istilah prestasi akademik yang mengacu pada tingkat pencapaian pembelajar dalam proses belajarnya.

Prestasi akademik sering dijadikan sebagai indikator keberhasilan proses pembelajaran. Maka dari itu, sangatlah krusial untuk mengeksplorasi berbagai aspek internal maupun eksternal yang memberi kontribusi dan pengaruh terhadapnya. Psikologi sebagai studi mengenai perilaku manusia dan proses mental yang mendasarinya (Feldman, 1996) memiliki sudut pandang khusus dalam memahami hal ini, dimana perhatian para ilmuwan psikologi mengarah pada faktor psikologis apa saja yang berkontribusi signifikan terhadap prestasi akademik. Berbagai penelitian terdahulu mencoba mengeksplorasinya dan beragam hasil pun diperoleh. Kemampuan kognitif (misal. Inteligensi) sudah dipercaya tidak menjadi satu-satunya faktor yang berpengaruh terhadap pencapaian akademik. Melainkan, aspek motivational dari seorang individu yang ditemukan berpengaruh besar pada prestasi. Aspek motivational individu merupakan fitur dari kepribadian yang mencerminkan kemauan/dorongan seseorang untuk bertindak (Furnham \& Chomorro-Premuzic, 2004). Beberapa hasil studi empiris menunjukkan pentingnya aspek kepribadian sebagai prediktor dalam prestasi akademik (Costa \& McCare, 1992; Mularsih, 2010; Hakimi, Hejazi, Lavasani, 2011; Komarajju, et al. 2011; Buju, 2013, Hazrati-Viari, et al, 2012). O'Connor dan Paunonen (2007, dalam Hazrati-Viari, et al, 2012) menguraikan rasionalisasi akan peran kepribadian sebagai prediktor prestasi akademik. 
Pertama, terdapat kecenderungan berperilaku yang tercermin dalam kepribadian yang dapat mempengaruhi kebiasaan-kebiasaan tertentu yang sangat terkait dengan pencapaian akademik seperti perseverence (ketekunan), conscientiousness (kesadaran), talkativeness (kecenderungan senang berbicara). Kedua, ketika kemampuan kognitif merujuk pada 'apa yang dapat dilakukan' oleh seorang pembelajar (what an individual can do), maka kepribadian merujuk pada 'apa yang akan dilakukan' pembelajar tersebut (what an individual will do). Ketiga, kepribadian sebagaimana kemampuan kognitif, akan dapat memprediksi pencapaian yang lebih baik pada pembelajar, secara khusus atribut kepribadian yang berhubungan dengan motivasi. Maka, dapat disimpulkan bahwa kepribadian memberi pengaruh yang unik terhadap pencapaian akademik

Mengingat bahwa terdapat berbagai perbedaan yang dimiliki pembelajar dalam mengelola pembelajaran, maka dimensi kepribadian menjadi perhatian penting. Hal ini dikarenakan, unsur motivasional tampak krusial dalam pengelolaan diri untuk proses belajar. Aspek motivational individu merupakan fitur dari kepribadian yang mencerminkan kemauan/dorongan seseorang untuk bertindak (Furnham \& Chomorro-Premuzic, 2008). Beberapa hasil studi empiris menunjukkan pentingnya aspek kepribadian sebagai prediktor dalam prestasi belajar (Costa \& McCare, 1992; Mularsih, 2010; Hakimi, et al. 2011; Komarajju, et al. 2011; Buju, 2013, Hazrati-Viari, et al, 2012). O'Connor dan Paunonen (2007, dalam Hazrati-Viari, et al, 2012) menguraikan rasionalisasi akan peran kepribadian sebagai prediktor prestasi belajar. Pertama, terdapat kecenderungan berperilaku yang tercermin dalam kepribadian yang dapat mempengaruhi kebiasaan-kebiasaan tertentu yang sangat terkait dengan pencapaian akademik seperti perseverence (ketekunan), conscientiousness (kesadaran), talkativeness (kecenderungan senang berbicara). Kedua, ketika kemampuan kogitif merujuk pada 'apa yang dapat dilakukan' oleh seorang siswa (what an individual can do), maka kepribadian merujuk pada 'apa yang akan dilakukan' siswa tersebut (what an individual will do). Ketiga, kepribadian sebagaimana kemampuan kognitif, akan dapat memprediksi pencapaian yang lebih baik pada siswa, secara khusus atribut kepribadian yang berhubungan dengan motivasi. Maka, dapat disimpulkan bahwa kepribadian memberi pengaruh yang unik terhadap pencapaian belajar siswa.

Oleh karena itu, peneliti tertarik mengkaji bagaimana pengaruh dari berbagai tipe kepribadian (dengan menggunakan The Big Five Personality Traits) terhadap prestasi akademik. Kepribadian (Feist \& Feist, 2008) adalah pola-pola dari sifat yang relatif permanen dan memiliki karakter unik secara konsisten dan yang pada akhirnya memunculkan perilaku individu. Kepribadian yang relatif menetap cenderung mendorong seseorang untuk berperilaku sesuai dengan tujuan dan tuntutan yang diberikan terhadap seseorang. Mc Crae dan Costa membagi teori kepribadian The Five Factor Model of Personality ke dalam 5 besar faktor atau dimensi kepribadian, yaitu neuroticism (neurotisme), extraversion (ekstraversi), openness (keterbukaan), agreeableness (persetujuan), dan concientiousness (hati nurani).

Pada dimensi neuroticism (neurotisme), pribadi dengan skor tinggi cenderung menjadi cemas, temperamental, mengasihani diri sendiri, dan rapuh terhadap gangguan yang berkaitan dengan stres. Dalam mengerjakan aktivitasnya, kecemasan yang tinggi berpengaruh negatif dengan motivasi untuk berprestasi (Corno, Mitman, \& Hedges, dalam Gage \& Berliner, 1998), yang pada akhirnya dapat mempengaruhi prestasi akademisnya. Tipe dimensi conscientiousness berasosiasi dengan perilaku disiplin, pekerja keras, teratur dan tertib seperti merencanakan dan mengorganisir tugas, berperilaku dengan rasa tanggung jawab dan berambisi sukses di bidang akademik. Selain itu conscientiousness juga berhubungan dengan pendekatan pembelajaran yakni achieving learning yang secara positif berpengaruh signifikan terhadap motivasi berprestasi, yang pada akhirnya berpengaruh terhadap prestasi akademik. Menurut De Raad \& Schouwenburg, siswa dengan tingkat extraversion yang tinggi cenderung akan memiliki prestasi yang baik dikarenakan tingginya energi ditambah dengan attitude yang positif yang mengarahkan pada motivasi untuk belajar dan memahami (Poropat, 2009). Dimensi ini menyangkut kelekatan seseorang yaitu bersahabat, memiliki hasrat untuk bersama orang lain, dan ingin menghibur orang lain atau mudah terharu. Tipe kepribadian openness memiliki kesamaan dengan aspek kreatif dan inovstif dalam motivasi berprestasi yang pada akhirnya berhubungan dengan prestasi akademik. Pribadi dengan openness yang tinggi secara konsisten mencari 
pengalaman-pengalaman yang beragam. Furnham \& Chamorro-Premuzic (2008) menunjukkan bahwa openness berkorelasi positif dengan prestasi belajar yang dimediasikan oleh deep learning. Tipe kepribadian agreeableness membedakan pribadi yang berhati lembut dari pribadi yang berhati kejam. Menurut Vermetten, Lodewijks \& Vermunt (dalam Poropat, 2009) dimensi ini berhubungan dengan kepatuhan terhadap perintah guru dan berusaha fokus kepada materi pembelajaran.

Minimnya literatur penelitian dalam negeri tentang topik kajian tipe kepribadian dan prestasi akademik menunjukkan masih rendahnya minat para praktisi pendidikan dan ilmuwan psikologi pendidikan di Indonesia, secara khusus di Sumatera Utara, untuk mengeksplorasi peran aspek kepribadian dalam menolong siswa untuk optimal dalam proses belajarnya. Sementara dalam penelusuran literatur, peneliti menemukan semakin banyak penelitian dengan topik ini dilakukan di negara maju maupun negara berkembang baik di Asia, Eropa dan Amerika Serikat (contoh: Zarafshani, Sharafi, \& Rajabi, 2011; Buju, 2013; Komarajju, et. al, 2011; Chamorro-Premuzic \& Furnham, 2003) yang menunjukkan minat atau trend penelitian akan peran aspek psikologis kepribadian terhadap proses dan prestasi belajar.

Penelitian ini dilakukan di lingkup peserta didik di tingkat pendidikan tinggi (mahasiswa). Dari sudut pandang psikologi perkembangan, secara umum mahasiswa berada pada tahap perkembangan remaja akhir memasuki dewasa muda, yaitu sekitar 17/18 tahun sampai dengan 21 atau 22 tahun. Pada tahap ini, kepribadian remaja sudah berkembang ke arah pola yang relatif menetap. Sehingga, identifikasi terhadap tipe atau dimensi kepribadian yang dominan sudah dapat menggambarkan secara spesifik kondisi karakteristik perilaku remaja tersebut. Selain itu, pola pendidikan di perguruan tinggi yang menuntut berkembangnya kemandirian belajar, dan pengambilan keputusan merupakan faktor-faktor yang mendorong berkembangnya pola perilaku tertentu yang relatif menetap. Berdasarkan pemaparan di atas, maka peneliti tertarik untuk melakukan penelitian dengan topik pengkajian tipe kepribadian dan hubungannya dengan prestasi akademik. Adapun tujuan penelitian ini adalah mengetahui bagaimana gambaran kepribadian, gambaran prestasi akademik, dan menguji apakah ada pengaruh kepribadian model Big Five Personality Traits terhadap prestasi akademik pada mahasiswa Universitas HKBP Nommensen (UHN). Adapun hipotesis utama yang dimunculkan dalam penelitian ini adalah terdapat pengaruh kepribadian yang signifikan terhadap prestasi akademik.

\section{METODE}

Pendekatan penelitian ini adalah pendekatan kuantitatif. Jumlah partisipan penelitian sebanyak 321 orang mahasiswa aktif (laki-laki: 124 , perempuan: 197) dari berbagai program studi di UHN. Pengumpulan data menggunakan skala psikologi untuk mengukur kepribadian, yakni Skala Big Five Personality. Skala Big Five Personality dalam penelitian ini diadaptasi dari Oliver's Big Five Inventory yang berbahasa Inggris yang telah diterjemahkan dalam Bahasa Indonesia dan sudah dilakukan uji validitas dan reliabilitas oleh Sianipar (2008). Prestasi akademik yang digunakan dalam penelitian ini adalah nilai Indeks Prestasi Kumulatif (IPK) pada semester genap TA. 2015/2016. Data yang diperoleh kemudian diolah secara bertahap. Pertama, analisis deskriptif untuk tipe kepribadian dan prestasi akademik. Kedua, analisis regresi untuk menguji hipotesis penelitian secara umum, dan untuk melihat kontribusi atau pengaruh masing-masing dimensi kepribadian terhadap prestasi akademik.

\section{HASIL DAN PEMBAHASAN}

Tahap pertama dalam pengolahan data adalah melakukan analisa deskriptif mengenai variabel-variabel penelitian. Pertama, analisa deskriptif mengenai dimensi kepribadian yang dominan untuk setiap partisipan penelitian. Berikut ini tabel yang menunjukkan distribusi frekuensi partisipan penelitian berdasarkan dimensi atau tipe kepribadian.

Tabel 1. Gambaran Sampel Penelitian

Berdasarkan Tipe Kepribadian

\begin{tabular}{lcc}
\hline Tipe kepribadian & Jumlah & Persentase \\
\hline Neuroticsm & 89 & $27.72 \%$ \\
Extraversion & 65 & $20.24 \%$ \\
Conscientiousness & 59 & $18.38 \%$ \\
Agreeableness & 58 & $18.06 \%$ \\
Openness & 50 & $15.57 \%$ \\
\hline Jumlah & 321 & $100 \%$ \\
\hline
\end{tabular}


Berdasarkan tabel di atas, dapat dilihat bahwa tipe atau dimensi kepribadian yang paling banyak adalah neuroticsm, yaitu sebanyak 89 orang $(27.72 \%)$. Sementara itu, dimensi kepribadian yang paling sedikit muncul adalah dimensi openness yaitu sebanyak 50 orang $(15.57 \%)$. Berikutnya adalah analisa deskripsi berdasarkan jenis kelamin dan tipe kepribadian. Tabel 2 berikut ini menunjukkan bahwa mahasiswa perempuan lebih banyak yang tergolong pada tipe kepribadian neuroticsm, disusul dengan extraversion, conscientiousness, agreeableness, dan openness. Sedangkan mahasiswa laki-laki lebih banyak yang tergolong pada tipe kepribadian neuroticsm, disusul dengan extraversion, agreeableness, conscientiousness, dan openness.

Tabel 2. Gambaran Sampel Penelitian Berdasarkan Jenis Kelamin dan Tipe Kepribadian

\begin{tabular}{ccccccc}
\hline JK & Neuroticsm & Ekstraversion & Conscientiousness & Agreeableness & Openness & Total \\
\hline Laki-laki & $29 / 23,3 \%$ & $24 / 23 \%$ & $22 / 17.7 \%$ & $28 / 22.5 \%$ & $21 / 16.9 \%$ & 124 \\
Perempuan & $60 / 30,4 \%$ & $41 / 20.8 \%$ & $37 / 18.7 \%$ & $30 / 15.2 \%$ & $29 / 14.7 \%$ & 197 \\
\hline Total & $\mathbf{8 9}$ & $\mathbf{6 5}$ & $\mathbf{5 9}$ & $\mathbf{5 8}$ & $\mathbf{5 0}$ & $\mathbf{3 2 1}$ \\
\hline
\end{tabular}

Analisa deskriptif selanjutnya berkaitan dengan bagaimana gambaran distribusi dari tipe kepribadian Big Five Personality bila ditinjau dari program studi sampel penelitian. Berikut ini tabel yang merangkum hal tersebut. Gambaran prestasi akademik dari sampel penelitian terangkum dalam tabel-tabel di bawah ini. Tabel 3 menunjukkan kondisi umum ukuran statistik untuk prestasi akademik (Mean $=3.15, \mathrm{SD}=0.46)$. Tabel 4 menunjukkan gambaran kondisi prestasi akademik berdasarkan jenis kelamin dan kategori prestasi akademik.

Tabel 3. Deskripsi Skor Prestasi Akademik

\begin{tabular}{ccccc}
\hline Variabel & Skor maksimum & Skor minimum & Rata-rata & Standar Deviasi \\
\hline Prestasi belajar & 4,00 & 1,75 & 3,15 & 0,46 \\
\hline
\end{tabular}

Tabel 4. Deskripsi Prestasi Akademik berdasarkan Jenis Kelamin

\begin{tabular}{|c|c|c|c|c|c|}
\hline \multirow{2}{*}{$\begin{array}{c}\text { Jenis } \\
\text { Kelamin }\end{array}$} & \multicolumn{4}{|c|}{ IPK } & \multirow[t]{2}{*}{ Jumlah } \\
\hline & IPK $<2.0$ & $2.0 \leq \mathrm{IPK}<2.75$ & $2.75 \leq \mathrm{IPK}<3.50$ & IPK $\geq 3.5$ & \\
\hline Laki-laki & 1 & 34 & 66 & 23 & 124 \\
\hline Perempuan & 1 & 26 & 105 & 65 & 197 \\
\hline Jumlah & 2 & 60 & 171 & 68 & 321 \\
\hline
\end{tabular}

Hipotesis utama dalam penelitian ini adalah tedapat pengaruh yang signifikan antara Big Five Personality terhadap prestasi akademik pada mahasiswa. Untuk menguji hipotesis ini, dilakukan analisa data lanjutan berupa analisis regresi. Dari hasil analisis regresi, diperoleh hasil nilai $R$ sebesar 0,26 . Nilai ini menunjukkan korelasi positif antara kedua variabel penelitian. Model regresi yang dihasilkan dari analisis regresi ini juga menunjukkan nilai $R^{2}=0,069$. Hal ini berarti bahwa variasi dalam prestasi akademik dapat dijelaskan sebesar $6.9 \%$ dari variasi tipe kepribadian Big Five Personality. Dengan kata lain, $93.1 \%$ variasi dalam prestasi akademik tidak dapat dijelaskan oleh tipe kepribadian Big Five personality. Tampaknya, banyak variabel lainnya yang mempengaruhi prestasi akademik disamping tipe kepribadian ini. Hasil analisis regresi juga menunjukkan nilai $\mathrm{F}=4,69$ dan signifikan pada $p$-value $<0.001$. Hal ini berarti bahwa model regresi yang dihasilkan ini, secara keseluruhan, dapat memprediksi dengan baik tentang prestasi akademik. Dengan demikian, dapat disimpulkan bahwa hipotesis utama dalam penelitian ini diterima, yaitu terdapat pengaruh yang signifikan dari tipe kepribadian Big Five Personality terhadap prestasi akademik. Analisis regresi lanjutan dilakukan untuk mengetahui model parameter dan nilai signifikansi untuk masing-masing dimensi kepribadian, seperti yang terangkum dalam tabel di bawah ini. 
Tabel 6. Hasil Analisis Regresi untuk masing-masing Dimensi Kepribadian dalam Big Five Personality terhadap prestasi akademik

\begin{tabular}{|c|c|c|c|c|c|c|}
\hline Dimensi & $\mathbf{B}$ & t-test value & p-value & \multicolumn{3}{|c|}{ Keterangan } \\
\hline Neuroticsm & 0.01 & 3.28 & $p<0.01$ & $\begin{array}{l}\text { Terdapat } \\
\text { signifikan }\end{array}$ & pengaruh & yang \\
\hline Extraversion & 0.01 & 2.45 & $p<0.05$ & $\begin{array}{l}\text { Terdapat } \\
\text { signifikan }\end{array}$ & pengaruh & yang \\
\hline Conscientiousness & 0.01 & 2.57 & $p<0.05$ & $\begin{array}{l}\text { Terdapat } \\
\text { signifikan }\end{array}$ & pengaruh & yang \\
\hline Agreeableness & -0.002 & -0.45 & $p>0.05$ & $\begin{array}{l}\text { Tidak ad } \\
\text { signifikan }\end{array}$ & pengaruh & yang \\
\hline Openness & 0.003 & 0.75 & $p>0.05$ & $\begin{array}{l}\text { Tidak ad } \\
\text { signifikan }\end{array}$ & pengaruh & yang \\
\hline
\end{tabular}

Berdasarkan hasil analisis regresi untuk menguji kontribusi masing-masing dimensi kepribadian terhadap prestasi akademik dalam model regresi yang dihasilkan, seperti yang terangkum dalam Tabel 6 di atas, maka dapat disusun kesimpulan sebagai berikut:

1. Terdapat pengaruh yang signifikan antara dimensi kepribadian neuroticsm terhadap prestasi akademik. Hal ini dikarenakan hasil analisis regresi menunjukkan $\beta$-value $=0,01 ; \quad$ t-tes value $=3,28 ;$ dan $p$-value < 0,5 .

2. Terdapat pengaruh yang signifikan antara dimensi kepribadian extraversion terhadap prestasi akademik. Hal ini dikarenakan hasil analisis regresi menunjukkan $\beta$-value $=0,01 ; \quad t$-tes value $=2,45 ;$ dan $p$-value $<$ 0,5 .

3. Terdapat pengaruh yang signifikan antara dimensi kepribadian conscientiousness terhadap prestasi akademik. Hal ini dikarenakan hasil analisis regresi menunjukkan $\beta$-value $=0,01 ; \quad$ t-tes value $=2.57$; dan $p$-value $<0,01$.

4. Tidak terdapat pengaruh yang signifikan antara dimensi kepribadian agreeableness terhadap prestasi akademik. Hal ini dikarenakan hasil analisis regresi menunjukkan $\beta$-value $=-0,002 ; \quad t$-tes value $=-0,454 ;$ dan $p$-value $>0,5$.

5. Tidak terdapat pengaruh yang signifikan antara dimensi kepribadian openness terhadap prestasi akademik. Hal ini dikarenakan hasil analisis regresi menunjukkan $\beta$-value $=0,003 ; \quad t$-tes value $=0,757$; dan $p$-value $>0.05$.
Analisis deskriptif mengenai tipe kepribadian menunjukkan $27.72 \%$ dari partisipan penelitian tergolong tipe neuroticsm. Dimensi neuroticsm berhubungan dengan dua emosi dasar yaitu fear (rasa takut) dan angry (rasa marah). Individu yang dominan pada dimensi ini bersifat nervous, high-strung, tense, worried, pessimistic, anxious, temperamental, self-pitying, self-conscious, emotional dan vulnerable to stressrelated disorders. Bila ditelusuri latar belakang budaya dari partisipan penelitian, hampir keseluruhan partisipan penelitian berasal dari latar belakang suku Batak. Pola karakter neuroticsm ini secara umum dikenal sebagai ciri dari individu dengan latar belakang budaya Batak, dimana orang Batak dikenal temperamentel, impulsif, cemas, dan rentan terhadap stres. Penelitian dengan hasil yang sama pernah dilakukan oleh Rosito \& Ambarita (2016) pada para siswa salah satu SMU Swasta favorit di kota Medan. Penelitian mereka mengenai tipe kepribadian menunjukkan bahwa sebanyak $27.9 \%$ dari 208 partisipan penelitian tergolong dalam tipe kepribadian neuroticsm. Hampir keseluruhan partisipan penelitian tersebut berlatar belakang suku Batak. Dominasi dalam tipe kepribadian neuroticsm ini dapat dikaitkan dengan budaya dari Suku Batak itu sendiri. Dewi (2004) dalam penelitiannya menemukan adanya perbedaan yang signifikan mengenai anteseden kemarahan interpersonal, trait anger, anger in expression-in, anger expression control-out, dan anger expression control-in pada orang Batak dan orang Jawa. Orang Batak terlihat ekspresif dalam mengungkapkan rasa marahnya dan trait anger cukup sering muncul terutama pada laki-laki. Pola-pola perilaku khusus yang tampak dari 
suku bangsa Batak dapat menggambarkan kepribadian mereka. Pola-pola perilaku tersebut dipengaruhi oleh nilai-nilai dari suku bangsa itu sendiri.

Gambaran deskripsi prestasi akademik menunjukkan bahwa untuk kategori $2.75 \leq$ IPK $<3.50$, perempuan lebih banyak yang mencapainya dibanding laki-laki. Demikian juga untuk kategori IPK $\geq 3.5$, dimana jumlah perempuan lebih tinggi daripada laki-laki.

Hasil analisis regresi menunjukkan bahwa secara keseluruhan model regresi yang dihasilkan, yakni kepribadian model Big Five Personality Traits dapat memprediksi prestasi akademik secara signifikan. Hal ini sejalan dengan penelitian yang dilakukan Hakimi, Hejazi \& Lavasani (2011) dimana mereka menemukan adanya korelasi kuat dan signifikan antara tipe kepribadian dengan pencapaian akademik pada mahasiswa, dimana karakteristik kepribadian memberikan kontribusi sebesar $48 \%$ terhadap pencapaian akademik

Dari hasil analisis regresi lanjutan, diperoleh hasil bahwa dimensi neuroticsm, extraversion, dan conscientiousness memberi kontribusi pengaruh signifikan terhadap prestasi akademik. Tampaknya, kondisi-kondisi kecenderungan untuk nervous, high-strung, tense, worried, pessimistic, anxious, temperamental, self-pitying, self-conscious, emotional dan vulnerable to stressrelated disorders (ciri dari dimensi neuroticsm) berhubungan dengan kemampuan mengarahkan energi untuk meningkatkan berbagai aktivitas belajar dan bertekun dalamnya (ciri dimensi conscientiousness) serta asertif dalam kehidupan sosial dan kehidupan belajarnya (ciri dimensi extraversion) yang pada akhirnya berhubungan dengan peningkatan prestasi. Satu penjelasan tentang ini bisa dikaitkan dengan tingginya persaingan yang terjadi di antara para mahasiswa memunculkan energi yang kuat untuk peningkatan prestasi. Kepercayaan bahwa prestasi yang baik dalam akademik sebagai salah satu cara memperoleh pengakuan sosial sangat dijunjung tinggi dalam suku Batak.

Hasil penelitian ini, secara khusus tentang signifikansi dari dimensi conscientiousness terhadap prestasi akademik, konsisten dengan hasil penelitian sebelumnya (misal:Saklofske, Austin, Mastoras, Beaton, \& Osborne, 2011; Chamorro-Premuzic \& Furnham, 2003; Chamorro-Premuzic \& Furnham, 2003; Caprara, Vecchione, Allesandri, Gerbino, \& Barbaranelli, 2011; Komarraju, et. al, 2011;
Komarajju, et. al. 2009; Hazrati-Viari, et. al, 2012; Hakimi, et. al, 2011). Sementara itu, kontribusi positif dan signifikan dari dimensi neuroticsm dan extraversion pada penelitian ini, ada yang sama dan ada yang berbeda dengan hasil penelitian sebelumnya.

\section{SIMPULAN DAN SARAN}

Berdasarkan hasil uji hipotesis utama dengan analisa regresi, diperoleh hasil bahwa kepribadian dengan model Big Five Personality Traits ini memberikan pengaruh signifikan terhadap prestasi akademik $\left(\mathrm{R}=0,26 ; \mathrm{R}^{2}=\right.$ $6,9 \% ; \mathrm{F}=4,69 ;$ p-value $<0,001)$. Walaupun kontribusinya tergolong kecil (sekitar 0.69\%), namun signifikan. Dalam penelitian selanjutnya, perlu dipertimbangkan adanya variabel mediator antara kepribadian dan prestasi akademik. Dimensi conscienstiousness ditemukan berkontribusi signifikan dengan prestasi, dan hasil ini sejalan dengan berbagai hasil penelitian sebelumnya. Hal yang unik dari penelitian ini adalah adanya kontribusi positif dan signifikan dari dimensi neuroticsm dan extraversion yang pada penelitian-penelitian sebelumnya justru tidak berkorelasi positif terhadap prestasi akademik.

Saran bagi para pendidik di lingkungan perguruan tinggi, agar mendorong terus berkembangnya sikap tekun, gigih, sistematis dan terorganisir dalam proses belajar mahasiswa, yang semakin mendorong pencapaian prestasi. Selain itu, keterbukaan dan asertifitas dalam proses belajar perlu dikembangkan misalnya melalui metode diskusi atau tugas kelompok yang terarah. Kecemasan dan kecenderungan untuk temperamental ketika dibarengi dengan pengendalian diri memberi keuntungan tersendiri bagi mahasiswa. Sehingga, implikasinya adalah dosen dapat mengajarkan dan melatih teknik manajemen stres pada mahasiswa, dalam mengarahkan dan mengendalikan emosi negatif yang dialami menjadi energi untuk melakukan hal yang positif.

\section{DAFTAR RUJUKAN}

Buju, S. (2013). Personality Profile of students with technical Academic Performance.

Procedia-Social and Behavioral Science. 78, 56-60

Caprara, G. V., Vecchione, M., Allesandri, G.., Gerbino, M., Barbaranelli, C. (2011). 
The contribution of personality traits and self-efficacy beliefs to academic achievement: A longitudinal study. British Journal of Educational Psychology, 81, 78-96. doi:10.1348/2044-8279.002004

Chamorro-Premuzic, T. \& Furnham, A. (2003). Personality traits and academic examination performance. European Journal of Personality, 17, 237-250. doi:10.1002/per.473

Chamorro-Premuzic, T. \& Furnham, A. (2003). Personality predicts academic performance: Evidence from two longitudinal university samples. Journal of Research in Personality, 37, 319-338. doi: 10.1016/S0092-6566(02)00578-0

Dewi, Z. L. (2004). Antesenden, Pengalaman, Ekspresi, dan Kontrol Marah pada Orang Batak dan Orang Jawa (Tesis): Depok: Program Pascasarjana Fakultas Psikologi Universitas Indonesia

Feldman, R., S. 1996. Understanding Psychology. USA : Mcgraw-Hill, Inc.

Feist, J. \& Feist, J.G. (2008). Teori Kepribadian, edisi keenam. Yogyakarta : Pustaka Belajar

Furnham, A. \& Chamorro-Premuzic, T. (2008). Personality, intelligence and approaches to learning as predictors of academic performance. University College London: Elsevier. doi:10.1016/j.paid.2008.01.003

Gage, N.L. \& Berliner, D. C. (1998). Educational Psychology, $6^{\text {th }}$ edition. USA : Houghton Mifflin Company

Hakimi, S., Hejazi, E., \& Lavasani, M.G. (2011). The relationship between personality traits and students' academic achievement. Procedia-Social and Behavioral Science. 29, 836-845. doi:10.1016/j.sbspro.2011.11.312

Hazrati-Viari, A., Rad, A. T., \& Torabi, S. S. (2012). The effect of personality traits on academic performance: the mediating role of academic motivation. Procedia-Social and Behavioral Science, 32, 367-371. doi: 10.1016/j.sbspro.2012.01.055
Komarraju, M., Karau, S.J., \& Schmeck, R. R. (2009). Role of the Big five personality traits in predicting college students' academic motivation and achievement. Personality and Individual differences, 19, 47-52

Komarraju, M., Karau, S.J., Schmeck, R. R., \& Avdic, A. (2011). The Big five personality traits, learning styles, and academic achievement. Personality and Individual differences, 51, 472-477. doi: 10.1016/j.paid.2011.04.019

Mularsih, H. 2010. Strategi pembelajaran, tipe kepribadian dan hasil belajar Bahasa Indonesia pada siswa sekolah menengah pertama. Makara, Sosial Humaniora. Vol 14, No 1, 65-74

Poropat, A. E. (2009). A Meta-analysis of the five factor model of personality and academic performance. American Psychological Association, 135 (2), 322-338. doi: 10.1037/a0014996

Rosito, A. C. \& Ambarita, T.F.A . (2016).Pengkajian tipe kepribadian dan hubungannya dengan prestasi belajar pada siswa sekolah menengah atas. Majalah Ilmiah Fakultas Psikologi Universitas HKBP Nommensen, Vo. 3, No. 1, hal 39-64.

Saklofske, D. H., Austin, E. J., Mastoras, S. M., Beaton, L., Osborne, S. E. (2012). Relationships of personality, affect, emotional intelligence and coping with student stress and academic success: Different patterns of association for stress and success. Learning and Individual Differences, 22, 251-257. doi: 10.1016/j.lindif.2011.02.010

Sianipar, S. (2008). Gambaran kepribadian suku bangsa batak Toba menggunakan Big Five Inventory. Skripsi. Universitas Sumatera Utara

Zarafshani, K. Sharafi, L., \& Rajabi, S. (2011). Using the Myers-Briggs Type Indicator (MBTI) in the teaching of entrepreneurial skills. International Journal of Science and Technology Education Research, 2, No 4, 66-74. 